\title{
Determinants of roundworms among primary school students in North Sumatera Province, Indonesia
}

\author{
Vierto Irennius Girsang ${ }^{1}$, Friska Vaulina Manik², Seri Asnawati Munthe ${ }^{3}$ \\ 1,2,3 Sari Mutiara Indonesia University. Email: Iren_ljc@yahoo.com
}

\begin{abstract}
Background: Worm infection was an environment-based disease caused by nematode class worms' intestine and transmitted through the soil. This condition could effect to their ability in school-age children to pay attentiont during the lessons.

Purpose: To determine the determinants of roundworms in elementary school students in Silahisabungan Subdistrict (Dairi), North Sumatera, Indonesia.

Methods: The case-control design with a total sample of 150 students taken from 5 elementary schools starting in grade 5 and 6 . This research instrument used a questionnaire.

Results: That there was no effect between hand washing habits at OR $1.90(95 \% \mathrm{Cl}: 0.697-5.180)$, there was no effect on nail hygiene by OR 1.19 (95\% Cl: $0.505-2828)$, there was no the influence of footwear use amounting to OR 1.68 (95\% Cl: $0.672-2225)$, there was an influence of the source of clean water of OR $=17.17(95 \% \mathrm{Cl}$ : $1,800-1163,78)$ and there is an effect of providing latrines at $\mathrm{OR}=5.55(95 \% \mathrm{Cl}: 1,128-27,398)$.

Suggestion: To students to be pay more attention in their personal hygiene, propose to teachers to be able to regularly check the student hygiene such as nail hygiene and make a source of information media in the school environment. Finally, this study asked the health centers to conduct child health screening and conduct counseling about personal hygiene.
\end{abstract}

\section{Keywords: Determinants; Roundworms; Primary School Students}

\section{INTRODUCTION}

Worm disease is closely related to daily living habits. Worm disease usually does not cause severe illness and the mortality rate is not too high but in chronic conditions in children can cause nutritional deficiencies which results in a decrease in endurance and in the end will cause disruption in child development. Especially for school-age children, this condition will result in their ability to take lessons will be reduced. Indonesia still has many diseases which are health problems, one of which is worms which are transmitted through the soil. These worms can cause a decrease in the condition of health, nutrition, intelligence and productivity of the sufferer so that many economic causes of loss. Worms cause loss of carbohydrates and proteins and blood loss, thus reducing the quality of human resources (Girsang, Munthe \& Pribadi, 2018; Kundaian, Umboh, \& Kepel, 2012; Ali, Zulkarnaini, \& Affandi, 2016). In 2012 World Health Organization (WHO) estimates that more than 1.5 billion people or $24 \%$ of the world's population are infected with worms transmitted through the soil and more than 270 million preschoolers live in areas where these parasites are transmitted intensively and require treatment and preventive measures (Lengkong, Joseph, \& Pijoh, 2012).

Proper grooming and healthy personal habits has an effect a roundworm infection, when the children have a poor showering habits can be infected with worms 441 times compared who have a good showering habits (Ratag, Tumbol, \& Dahar, 2013). Nail hygiene has a significant influence on the incidence of roundworm in which students who have bad nail hygiene have a chance of 25,186 times infected with roundworm compared to students who have good nail hygiene (Fitri, Saam, \& Hamidy, 2012). Outside the home, should wear shoes or sandals can prevent the entry of hookworms into the body through the soles of the feet, and to give beauty to the wearer (Martila, Sandy, \& Paembonan, 2015). Based on the results of laboratory tests, it showed that 36 people were positively affected by roundworm, 4 were positive for Ascaris lumbricoides and Trichuris trichiura, as many as 31 people were affected by Ascaris lumbricoides and as many as 1 person was 
Malahayati International Journal of Nursing and Health Science, Volume 02, No.2, September 2019: 86-91

Determinants of roundworms among primary school students in North Sumatera Province, Indonesia

affected by Trichuritis trichiura. Finally, researcher to determine the determinants of roundworms in elementary school students in Silahisabungan Subdistrict (Dairi) , North Sumatera, Indonesia in 2017.

\section{RESEARCH METHODS}

An analytical study using a design case control to find, namely to study the determinants of roundworm in primary school children by comparing case groups (roundworm positive school children) and control groups (children with negative worms). The location of this study were five elementary schools and The population in this study was elementary school students in grade $\mathrm{V}$ and grade VI as many as 774 students. Researchers used secondary data from 36 Environmental Health and Disease Control Centers (EHDCC). Samples for researchers made a comparison of 1: 4 including a case group of 30 students and a control group of 120 students in order to reach a sample of 150 students. Bivariate analysis used the test chi-square, a significant test using the meaning limit $\alpha=0.05$ with a significant level of $95 \%$. Multivariate analysis to predict the occurrence of roundworm on someone by conducting a multiple logistic regression analysis statistical test.

\section{RESEARCH RESULTS}

Based on the results of the study it was found that there was no relationship between hand washing habits and roundworm in children of elementary school students with a value ( $p$-value) 0.059 ). From the results of the calculation $O R$ value 2.48 (Confidentace Interval $95 \%=0.945$ $6,542)$. There was no correlation between nail hygiene and roundworm in children of elementary school students with a value ( $p$-value 0.327 ). The results of the calculation OR 1.49 (Confidentace interval $95 \%=0.667-3.347)$. There was no association with the use of footwear with roundworm in children of elementary school students with a value ( $p$-value 0.096). From the results of calculation the value OR 2.10 (Confidentace Interval 95\% $=0.867-5.101$ ).

The results of the study also showed that there was a relationship between the source of clean water and the incidence of roundworm in children of elementary school students. Source of clean water is a risk factor for the incidence of roundworm in children of elementary school students. The results of the calculation OR found that the value was 18.3 (Confidentace Interval 95\% $=1,965-170,60)$. Otherwise, the study showed that there was the relationship of Provision of Latrine with the incidence of roundworm in children of elementary school students. Provision of latrines was a risk factor for roundworm in children of elementary school students. Based on the results it showed that the calculation OR was 6.0 value (Confidentace interval 95\%=1.266-28,442).

Vierto Irennius Girsang', Friska Vaulina Manik', Seri Asnawati Munthe ${ }^{3}$

Sari Mutiara Indonesia University. Email: Iren_ljc@yahoo.com 
Malahayati International Journal of Nursing and Health Science, Volume 02, No.2, September 2019: 86-91

Determinants of roundworms among primary school students in North Sumatera Province, Indonesia

Table 1. Distribution of Respondents by Determinants of Roundworm Infection

$\mathrm{N}=150$

\begin{tabular}{|c|c|c|c|c|c|c|c|}
\hline \multirow{2}{*}{ Variable } & \multicolumn{2}{|c|}{ Cases } & \multicolumn{2}{|c|}{ Controls } & \multirow{2}{*}{ OR } & \multirow{2}{*}{$95 \% \mathrm{Cl}$} & \multirow{2}{*}{$\mathrm{p}$-value } \\
\hline & $n$ & $\%$ & $\mathrm{n}$ & $\%$ & & & \\
\hline \multicolumn{8}{|c|}{ Hand washing before taking food } \\
\hline Occasionally & 24 & 24,5 & 74 & 75.5 & & & \\
\hline Regularly & 6 & 11.5 & 46 & 88.5 & $2: 48$ & $0945-6542$ & 0.059 \\
\hline \multicolumn{8}{|l|}{ Nail Cleanliness } \\
\hline Dirty and untrimmed & 17 & 23.3 & 56 & 76.7 & & & \\
\hline Clean and trimmed & 13 & 16.9 & 64 & 83.1 & 1.49 & $0.667-3.347$ & 0.327 \\
\hline \multicolumn{8}{|l|}{ Use of Foot wears } \\
\hline Regularly & 22 & 24.4 & 68 & 75.6 & 2.10 & & \\
\hline Occasionally & 8 & 13.3 & 52 & 86.7 & & $0.867-5.101$ & 0.096 \\
\hline \multicolumn{8}{|l|}{ Sources of Water } \\
\hline Ineligible & 4 & 80 & 1 & 20 & & & \\
\hline Qualify & 26 & 17.9 & 119 & 82.1 & 18.3 & $1.965-170.60$ & 0,006 \\
\hline \multicolumn{8}{|l|}{ Provision of toilets } \\
\hline Ineligible & 4 & 57.1 & 3 & 42.9 & 600 & $1266-28442$ & 003 \\
\hline Eligible & 26 & 18.2 & 117 & 81.8 & 6.00 & $1.266-28.442$ & 0.03 \\
\hline
\end{tabular}

The multivariate test results obtained the final result for the risk factor for roundworm was the source of clean water with the value of $P$ - value $=0.01$ and $O R$ value $=17.17$ and provision of latrines with the value $P$ - value $=0.03$ and $O R$ value $=.5,55$.

Table 2. Multivariate Analysis With Determinant of Worm Infections

\begin{tabular}{lccccc}
\hline \multicolumn{1}{c}{ Variable } & OR & $\begin{array}{c}\boldsymbol{\beta} \\
\text { Coefficient }\end{array}$ & $\begin{array}{c}\text { Standard } \\
\text { Error }\end{array}$ & p-value & $\mathbf{9 5 \%} \mathbf{C l}$ \\
\hline Hand Washing Habit & 1.90 & 0.64 & 0.97 & 0.20 & $0.697-5.180$ \\
Nail Hygiene & 1.19 & 0.17 & 0.52 & 0.68 & $0.505-2.828$ \\
Use of Footwear & 1.68 & 0.52 & 0.79 & 0.26 & $0.672-4.225$ \\
Clean Water Sources & $1.800-$ & 2.84 & 19.76 & 0.01 & 17.17 \\
Provision of Latrine & 163.786 & 1.71 & 4.52 & 0.03 & 5.55 \\
Constant & $1.128-$ & & & & \\
\hline
\end{tabular}

Based on multivariate analysis with multiple logistic regressions found that to predict or estimate the affected individual to experience pain or roundworm incident by exposed a number of variables based on values of independent measured the patient.

\section{DISCUSSION}

Soil-Transmitted Helminthes could be transmitted by eggs in infected human excrement. Adult worms lived in the human intestine where the adult worms produced thousands of eggs every day. It could be happened because eggs 
were swallowed by children who played on contaminated soil without first washing their hands (Pasaribu, 2016).

The results of conducted research in elementary schools used a questionnaire, some students had noticed the cleanliness of their hands using water and soap but most students had not paid attention to the cleanliness of their hands by not washing their hands with soap at the time before eating, finishing defecation, and also when they finish playing the ground, although students do not wash their hands with soap but the behavior of hand washing habits is open $n$ activities that are directly related to the effort to enter worm eggs into the body through hands or these risk factors were affected by the presence of other variables. Bad hygiene of roundworm had risk 22.41 times which was greater than that of good. Various efforts made in direct action can improve hygiene individual. These included the check of children hygiene at least 1 time a week, punishing children who did not wear footwear, learning materials about roundworm during the clocks, activating of medical school efforts and the formation of small doctors in all elementary schools. Whereas indirect efforts, it could be carried out through the distribution of posters, leaflets, pictures of worms to schools (Ginting, 2006). Nail hygiene had a significant influence on the incidence of roundworm where students who have bad nail hygiene had a chance of 25,186 times infected with roundworm compared to students who had good nail hygiene. Long and unkempt nails would become a place where various impurities contain various materials and microorganisms including bacteria and worm eggs (Fitri, Saam, \& Hamidy, 2012).

In this study most of the students had clean, short and clean nails, and cut their nails regularly, they realized that long and dirty nails were not good for health and students did not put their fingers in their mouth and did not bite their nails while playing. Personal hygiene is important; prevention of nails should be cut short to avoid transmission of worms from hand to mouth.

Worm infections could be affected because students played on the ground, making it easier to get infected with worms. Personal hygiene such as nail hygiene was one of the factors that play a role in infection with roundworm. Some respondents who did not maintain dirty nail hygiene were probably caused by ignorance of the respondents. This research showed that some students when playing outside the home or when mutual cooperation in schools did not wear footwear. Students who did not wear footwear while playing on the ground, it could be at risk of worm infections because hookworms could penetrate the skin and enter the body. The use of footwear was suspected not a risk factor that was directly related to the incidence of roundworm. These risk factors were affected by other variables. According to this study, it could not be clearly known whether the use of footwear was always done every time out of the house and also when playing outside the home. The results of interviews conducted in elementary school children, some elementary school children did not or rarely drank worm medicine, some of them had reasons that parents did not give, and some gave reasons they did not know when to take worm medicine. The program to administer drug prevention for roundworm in elementary school children and toddlers had been determined by the government that the community did not need to pay for the medicine, giving the drug at least once a year to prevent children from worming. Primary school children took medication distributed at school health screening activities. Toddler children take medicine which is shared with the provision of vitamin A (Girsang, Munthe \& Pribadi, 2018; Kundaian, Umboh, \& Kepel, 2012; Ali, Zulkarnaini, \& Affandi, 2016).

Based on multivariate test with multiple logistic regression test which starts from the selection of selected variables to multivariate analysis to the final model on the use of footwear against roundworm, the result of pure OR value is 1.68 (95\% Cl: 0.672-4.225). This result did not match the research of Yulianto (2007) with logistic regression tests showing the factor of footwear use including variables that influence the occurrence of roundworm infection with the value of $\mathrm{P}_{\text {Value }}=0.02 \mathrm{OR}=2.797(95 \% \mathrm{Cl}: 4.556-5,426)$. Clean water had a significant effect on the incidence of roundworm. Based on the results of this study, it was found that most students used mountain water which was channeled into the house through pipes, but there were students who 
Malahayati International Journal of Nursing and Health Science, Volume 02, No.2, September 2019: 86-91

Determinants of roundworms among primary school students in North Sumatera Province, Indonesia

used Toba Lake water used in their daily needs. In this study, it was suspected that the source of clean water which is categorized as fulfilling the requirements was not necessarily already free from contamination of worm eggs (Proverawati \& Rahmawati, 2012; Mustikawati, 2013; Kundaian, Umboh, \& Kepel, 2012).

Defecation (defecation) behavior that was not good and in any place even though it has a family toilet was thought to be a risk factor in hookworm infection. Theoretically, hookworm eggs needed soil media for their development. The presence of hookworm eggs in the feces of patients who carried out defecation activities in open soil further increases the chances of transmitting hookworm larvae to surrounding communities. Habits such as defecation around the house, eating without washing hands, playing on the ground around the house, especially toddlers continue to get infected (Lidia, Ridha, \& Trisnawati, 2016). In this study most students already had a toilet in the house, but there were students who have a floor made of soil and also some students do not have a toilet so that they will go to the river near their house if they defecated. Provision of latrines in the category that met the conditions did not necessarily avoid infection with roundworm; it could be influenced or followed by student behavior that is not always controlled by parents.

Based on multivariate tests with multiple logistic regression tests starting from the selection of selected variables to multivariate analysis up to the final model in the source of clean water for roundworm, the results of pure OR values were 5.55 (95\% Cl: 1,128-27,398). This research matched to Yudhastuti (2012) with the value of $P_{\text {value }}=0,000$ and the value of $\mathrm{OR}=5.42(95 \% \mathrm{Cl}$ : $3,554-8,550)$. Provision of clean water and family latrines that did not meet the requirements could be a risk factor for infectious diseases that are transmitted through soil and water such as roundworm. Good latrine ownership could reduce the prevalence of worms, but it might be followed by children's behavior, socio-economic, and good clean water facilities. The factors that cause high earthworm infections are the low level of clean and healthy behavior such as hand washing habits before eating and after defecation (bowel movements), hygiene of nails, snacks in any place where cleanliness cannot be controlled, defecation is not in the toilet which causes soil and environmental pollution by feces containing worm eggs and the availability of clean water sources (Kartini, 2016).

\section{CONCLUSION}

There was no effect of hand washing habits, on nail hygiene, footwear use and clean water sources on primary school children with $\mathrm{OR}=$ 17.17 (95\% Cl: 1,800-1 163,78). There was an effect of providing latrines to elementary school children with an OR value of 5.55 (95\% Cl: 1,12827,398).

\section{RECOMMENDATION}

The writer suggested to primary school students in Silahisabungan district to maintained personal hygiene better by paying attention to hand washing habits, nail hygiene, to use of footwear and using clean water for daily needs and when defecation is carried out not in places, to avoided worm disease. This study suggested to teachers did periodic checks such as nail examinations and make sources of information such as posters about the dangers of roundworm around the school environment.

\section{REFERENCES}

Ali, R. U., Zulkarnaini, Z., \& Affandi, D. (2016). Hubungan personal hygiene dan sanitasi lingkungan dengan angka kejadian kecacingan (soil transmitted helminth) pada petani sayur di Kelurahan Maharatu Kecamatan Marpoyan Damai Kota Pekanbaru. Dinamika Lingkungan Indonesia, 3(1), 24-32.

Fitri, J., Saam, Z., \& Hamidy, M. Y. (2012). Analisis faktor-faktor risiko infeksi kecacingan murid sekolah dasar di Kecamatan Angkola Timur Kabupaten Tapanuli Selatan tahun 2012. Jurnal IImu Lingkungan, 6(2).

Ginting, L. (2006). Infestasi Kecacingan pada Anak SD di Kecamatan Sei Bingai Langkat, Sumut, 2005. Kesmas: National Public Health Journal, 1(1), 18-25. 
Malahayati International Journal of Nursing and Health Science, Volume 02, No.2, September 2019: 86-91

Determinants of roundworms among primary school students in North Sumatera Province, Indonesia

Girsang, V. I., Munthe, R., \& Pribadi, T. (2018). Pengaruh kejadian kecacingan terhadap kadar HB dan indeks masa tubuh anak. Holistik Jurnal Kesehatan, 12(4), 265-270.

Kartini, S. (2016). Kejadian Kecacingan pada Siswa Sekolah Dasar Negeri Kecamatan Rumbai Pesisir Pekanbar. Jurnal Kesehatan Komunitas, 3(2), 53-58.

Kundaian, F., Umboh, J. M., \& Kepel, B. J. (2012). Hubungan Antara Sanitasi Lingkungan dengan Infestasi Cacing pada Murid Sekolah Dasar di Desa Teling Kecamatan Tombariri Kabupaten Minahasa. Kesmas, 1(1), 21-27.

Lengkong, B. R., Joseph, W. B., \& Pijoh, V. D. (2012). Hubungan antara Higiene Perorangan dengan Infestasi Cacing pada Pelajar Sekolah Dasar Negeri 47 Kota Manado

Lidia, M., Ridha, A., \& Trisnawati, E. (2016). Faktor Perilaku Anak Yang Berhubungan Dengan Penyakit Kecacingan Pada Anak Di Desa Pahokng Kecamatan Mempawah Hulu Kabupaten Landak. Jumantik, 3(1).

Martila, M., Sandy, S., \& Paembonan, N. (2015). Hubungan Higiene Perorangan dengan Kejadian Kecacingan pada Murid SD Negeri Abe Pantai Jayapura. Jurnal Plasma, 1(2), 8796
Mustikawati, I. S. (2013). Perilaku personal hygiene pada pemulung di TPA kedaung wetan tangerang. In Forum IImiah (Vol. 10, No. 1, pp. 27-35).

Pasaribu, R. I. (2016). Hubungan higiene perorangan dengan kejadian kecacingan soiltransmitted helminthes pada siswa sdn 060952 di kelurahan martubung kecamatan medan labuhan tahun 2016 (Doctoral dissertation, Universitas Sari Mutiara Indonesia).

Proverawati, A., \& Rahmawati, E. (2012). Perilaku hidup bersih dan sehat (PHBS). Yogyakarta: Nuha Medika.

Ratag, B. T., Tumbol, R., \& Dahar, A. (2013). Hubungan antara higiene perorangan dengan infestasi nematoda usus pada siswa sekolah dasar Gmist Nazareth Lesa Kecamatan Tahuna Timur Kabupaten Kepulauan Sangihe.

Yudhastuti, R. (2012). Kebersihan diri dan sanitasi rumah pada anak balita dengan kecacingan. Jurnal Kesehatan Masyarakat Nasional, 6(4), 173-178. 